\title{
A harckocsik védelmének fejlődése a páncélelhárítás fejlődésének tükrében és az aktív védelmi rendszerek (APS)
} megjelenése nurresz

\section{Az AKTív vÉDELMI RENDSZEREK BEMUTATÁSA}

\section{DROZD}

Talán kevesen gondolnák, hogy a szovjet konstruktőrök az ilyen, elsősorban elektronikai-számítástechnikai kihívásokat jelentő fejlesztésekben is az élen jártak, de bizonyos, hogy az első működő harckocsi aktív védelmi rendszert ők alkották meg. A rakéta páncéltörő gránátok ellen kidolgozott Drozd (vagyis „rigó”) nevű eszköz első prototípusát már 1978-ban kipróbálták, de végül a jelentősen korszerüsített Drozd-2-es lett az az első aktív védelmi célú eszköz, amelyet rendszeresítettek és harctéren is alkalmaztak [16]. Egyetlen, 24,5 GHz-en üzemelő doppler radarja előre nézett, a hozzá tartozó számítógép csak az 50 és $500 \mathrm{~m} / \mathrm{s}$ sebességtartományban közeledő lövedékeket tekintette fenyegetésnek, mivel azok tömegét nem tudta felismerni, így elvben egy puskagolyó is aktiválhatta volna a rendszert. A célként detektált lövedékek megsemmisítésére a torony két oldalán elhelyezett 5-5 vetőcsőből 107 mm-es rakétákat lőtt ki, amelyek vízszintesen kb. $180^{\circ}$-os, függőlegesen $40^{\circ}$-os mezőben védték a harckocsit. A lövedéket a rakéták 7 méterrel a cél előtt robbanva, 3 grammos repeszek felhőjével semmisítették meg.

Eredetileg a hadsereg T-72-es harckocsijait szándékozták általa korszerüsíteni, de a viszonylag nagy szerelvények nem tették volna lehetővé a deszanthajón történő szállítást, így végül a tengerészgyalogság elavult T-55-ös harckocsijaiból szereltek fel mintegy 250 példányt 1981ben a Drozd-al. Ezeket Afganisztánban be is vetették, és igen értékes tapasztalatokkal gazdagodtak. A feljegyzett 80\%-os megsemmisítési arány egy ilyen úttörő rendszer esetén kiemelkedőnek számít, ugyanakkor az is tény, hogy az eszköz csak egyetlen támadó lövedéket volt képes semlegesíteni, utána mintegy 10 percig tartott, amíg újra feltöltötték a vetőcsöveket. A repeszek halálos veszélyt jelentettek a támogató gyalogosokra, és amellett, hogy rendkívül drága is volt, jelentős méretei és tömege miatt nem fejlesztették tovább.

\section{ARENA}

Utódja az Arena, már a '90-es évek korszerübb technikáját alkalmazta. A tornyon továbbra is egyetlen, méretes radart helyeztek el, de ennek látószöge már közel $300^{\circ}$-os volt. A célok sebességtartományát ezúttal 70 és 700 m/s között

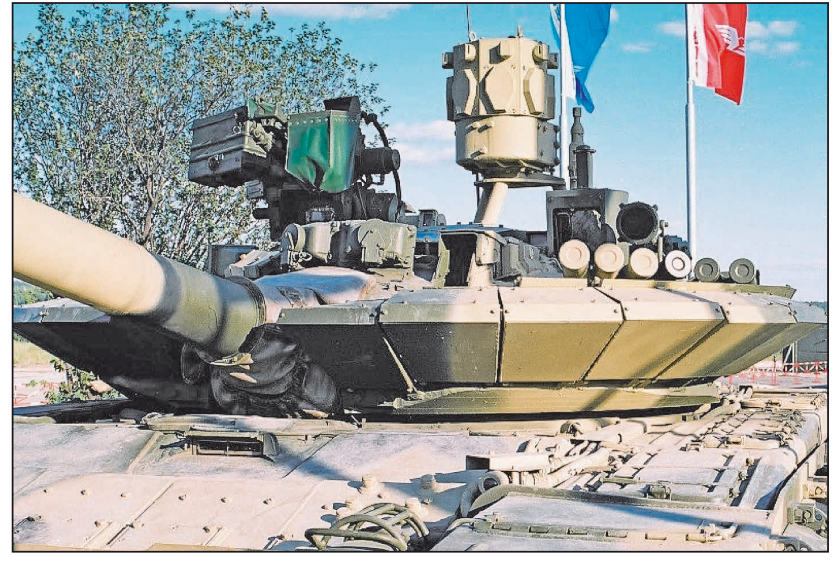

8. ábra. Az Arena-E aktív védelmi rendszer egy T-72-es harckocsi tornyán

határozták meg. A védelmet a tornyon körívesen elhelyezett 22-26 töltet adta, ezek közül a számítógép már csak azt az egyet aktiválta, amelynek pozíciója a leginkább megfelelő volt a közeledő rakéta elpusztítására, így elvben több támadás ellen is képes volt védelmet nyújtani. Az Arenával 1993 után T-80-as harckocsikat szereltek fel viszonylag nagyobb számban, amelyek - $80 \%$ fölötti megsemmisítési arányt elérve - az első csecsen háború alatt átestek a tűzkeresztségen. A felrobbanó ellentöltetek 2-30 méteren belül továbbra is súlyosan veszélyeztették a saját gyalogságot.

A rendszer teljes tömege függött a hordozó platformtól is, de mindenképpen a még elfogadható 1,1-1,3 tonna körül mozgott, ugyanakkor jelentős, kb. 1 kW-os teljesítményigénye komoly terhelést rótt a harckocsik fedélzeti villamos rendszereire. Az akkumulátorok csupán néhány percig voltak képesek táplálni, így a működtetése érdekében álló helyzetben is folyamatosan járatni kellett a motort. Arena-E néven exportváltozata is készült [17] és a dél-koreai Black Panther (fekete párduc) harckocsikat kívánták vele felszerelni, de ez az üzlet végül meghiúsult. Bár igazából csak a szovjet gyártmányú RPG-k ellen ért el sikereket, elvben védelmet nyújtott a Hellfire és TOW rakéták, illetve a HEAT kumulatív lövedékek ellen is, sőt még az űrméret alatti páncéltörő lövedékek ellen is nyújtott némi védelmet. Sebességük jóval meghaladta a rendszeresített végső változat által célnak tekintett tartományt, de a próbákon bebi-

Okl. mk. alezredes, Nemzeti Közszolgálati Egyetem Katonai Műszaki Doktori Iskola, doktorandusz hallgató, vegvari.zsolt@hm.gov.hu ORCID: 0000-0003-2543-6049 


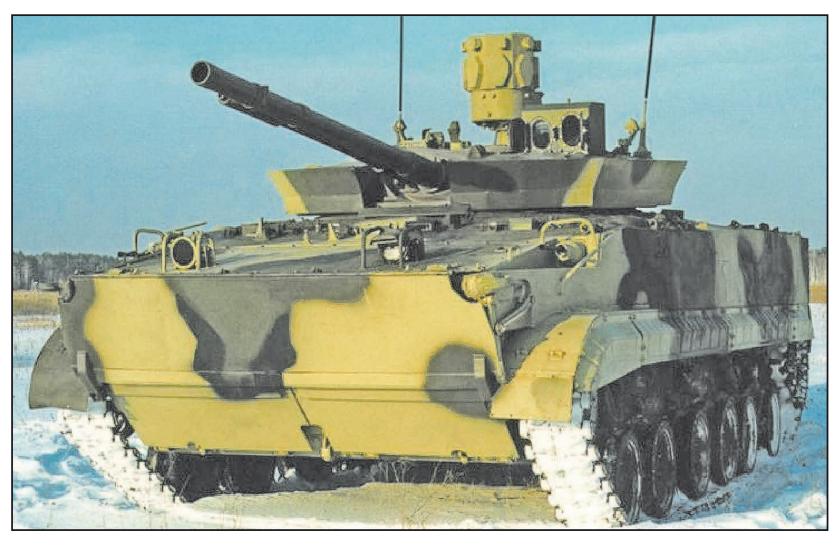

9. ábra. Az Arena-E elég könnyű ahhoz, hogy lövészpáncélosra is elhelyezhessék. A képen egy BMP-3-as harcjármü

zonyosodott, hogy a repeszek ugyan nem semmisítették meg a jelentős mozgási energiájú lövedéket, mégis módosították annyira a pályáját, hogy a becsapódás már számos esetben nem volt képes áttörni a páncélzatot.

\section{SHTORA}

Még a szovjet idők végén, 1988-ban fejlesztették ki a Shtora, azaz „függöny” nevű, ködvető elven működő aktív védelmi rendszert (soft-kill APS-t), amelyet aztán 1995-től szereltek fel nagyobb számban T-90-es harckocsikra [18] és máig alkalmazásban vannak. Ez a rendszer kizárólag a lézervezérlésű rakéták (pl. HOT, TOW) ellen nyújt védelmet, de azok ellen kimagasló hatékonysággal. A torony két oldalán elhelyezett lézerszenzorok vízszintesen elvben körkörös, függőlegesen mintegy $30^{\circ}$-os érzékelési tartománynyal rendelkeznek, és nem csupán detektálják a lézert, de a forrás irányát is meghatározzák néhány fok pontossággal. Ezt követően a megfelelő szögben aktiválódnak a körben elhelyezett füstgránátok, és kb. három másodperc alatt mintegy 50-70 méteres füstfalat hoznak létre a lézer irányában, amelyet nagy erejű infrafénnyel világítanak meg, teljesen elvakítva a közeledő rakétát. A füst kb. 20 másodperc múlva eloszlik. Mivel a rendszer tömege mindössze $400 \mathrm{~kg}$, a későbbiekben BMP-3-as lövészpáncélosokat is elláttak vele.

10. ábra. T-90A harckocsi a Shtora aktív védelmi rendszerrel. Ez volt az egyik első kép, amely a rendszerröl megjelent a nyugati sajtóban

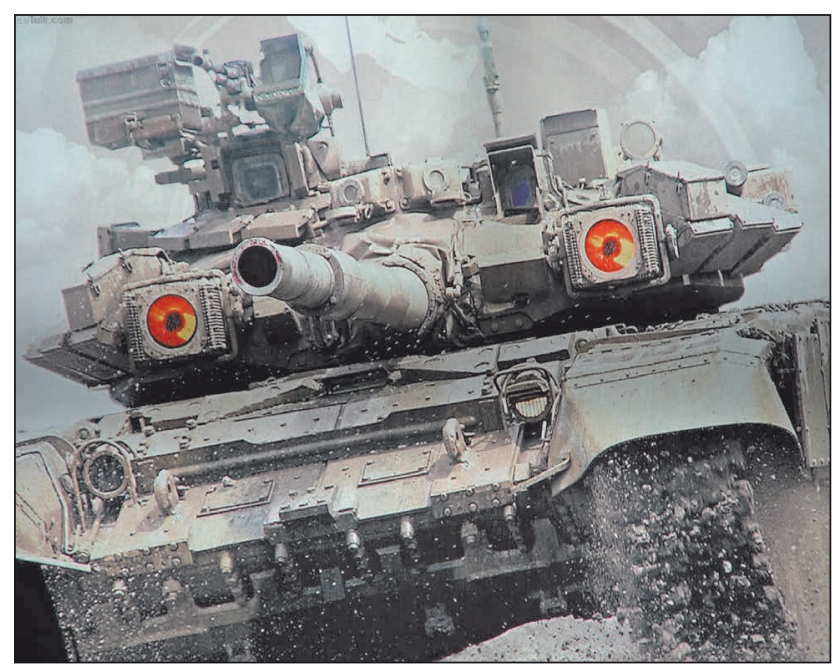

AFGANIT

Természetesen a T-14 Armatát, illetve a bázisán kifejlesztett T-15-ös lövészpáncélost is ellátták APS-el [19], amely immáron nem egy utólagosan felszerelt eszköz, hanem a harcjármű tervezésekor kezdettől számoltak vele, és a fedélzeti rendszerek szerves részét képezi. Az Afganit nevű berendezésről még nem lehet sokat tudni, de állítólag 5 Mach sebességig minden lövedéket képes detektálni milliméteres hullámhosszú radarjával, illetve az azt kiegészítő UV szenzorral, ami a rakétahajtóművek után keletkező ionizált levegő-részecskéket érzékeli. Miután a repeszfelhő az ürméret alatti lövedékek ellen is hatásos, visszatértek a hard-kill koncepcióhoz (közvetlen fizikai kontaktus útján működő aktív védelmi rendszerek). A tényleges hatékonysága nem ismert, de technológiáját tekintve mindenképpen meghaladja a jelenleg publikus nyugati típusokat.

\section{TROPHY}

Az izraeli Rafael cég a 2000-es évek elejétől fejlesztette saját hard-kill rendszerét, amelyet 2007-ben Trophy, azaz „trófea” néven mutattak be. Szinte azonnal döntés született arról, hogy a Merkava legújabb változatán a 2004-ben rendszeresített Mk4-esen széria-felszereléssé teszik az eszközt, illetve 2009 óta a régebbi verziókat is folyamatosan felszerelik vele. Pontos paraméterei nem ismertek, illetve a folyamatos fejlesztések miatt változnak is, de az biztos, hogy már a legkorábbi változat is $360^{\circ}$-os védelmi zónát biztosít, és a repesztöltetek 10-30 méteren belül megsemmisítik a támadó rakétákat.

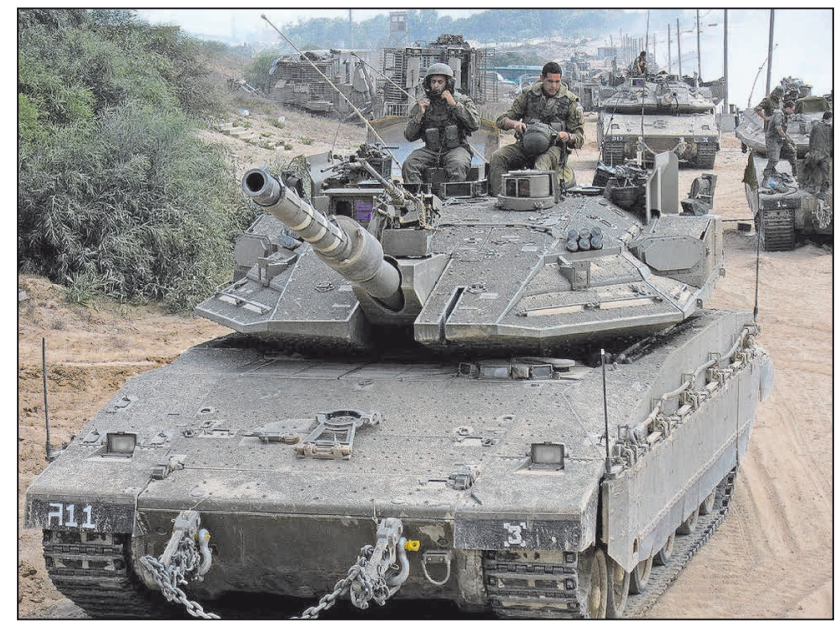

11. ábra. A Merkava Mk4-esen az APS már nem utólag felszerelt eszköz, hanem a gyártás kezdetétől a konstrukció szerves része

Az Izraeli Védelmi Erők folyamatos, változó intenzitású harcot folytatnak a gerilla taktikát alkalmazó félkatonai szervezetekkel. Mivel ezek fegyverzetében nincs páncéltörő löveg, avagy harckocsi, a Trophy-t kimondottan a páncéltörő rakéták elleni védelemre optimalizálták [20], és ezen a területen nem is vallott szégyent. 2011-ben, 2012ben és 2014-ben jegyeztek fel több olyan esetet is, hogy a rendszer különféle ellenséges rakétákat (orosz gyártmányú RPG-29es, AT-7-es, Kornet-E és Konkurs típusokat) semlegesített. A Trophy a kilőtt repesztölteteket automatikusan újratölti, ami nyilvánvalóan megnöveli a berendezés méretét és tömegét, de óriási előnyt jelent a városi harc során. Ugyanakkor szintén a városi harc következményeként fo- 


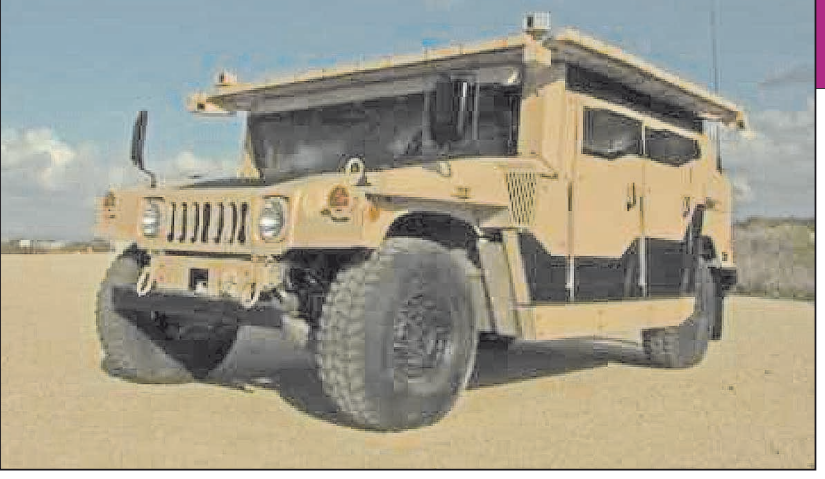

12. ábra. Trophy LV aktív védelmi rendszer egy Humvee katonai terepjárón. A négy sarokban jól láthatók az érzékelők

kozottan jelentkezik a saját gyalogság veszélyeztetése, amit az izraeli mérnökök a repesztöltet fókuszálásával, illetve pontosabb radarral próbálnak orvosolni.

Az Amerikai Egyesült Államok hadserege lényegében a megjelenés óta folyamatosan próbálja az eszközt, számos éleslövészetet is végrehajtottak vele, de konkrét megrendelés mindeddig csak 2013-ban érkezett, néhány tucat LAV III-as harcjárművet szereltek fel vele. Az izraeli APSnek nemrégiben kifejlesztették a könnyített, azaz „Trophy Lite" verzióját is. A lokátor azonos a nagy testvérével, de a könnyű harcjárművek igényeinek megfelelően módosították a töltetek karakterisztikáját (azaz a környező gyalogság védelme érdekében lefelé nincs repeszhatás), illetve csökkentették a töltetek számát is. Az azóta Trophy LV-ösnek (Lyght Vehicle - könnyü jármü) átkeresztelt verziót - a Merkavákra szerelt változatot Trophy HV (Heavy Vehicle) néven kínálják -, elkezdték felszerelni az izraeli lövészpáncélosokra, sőt még a viszonylag kis teherbírású $4 \times 4$-es páncélozott terepjárókra is.

\section{IRON FIST}

A „vasököl” nevű rendszert szintén Izraelben fejlesztette az Israel Military Industries (IMI) nagyjából egy időben a Trophy-val. Több harcjárművön is kipróbálták, de az Izraeli Védelmi Minisztérium megszüntette a terv finanszírozását, miután 2009-ben végleg a Trophy mellett tette le a voksát. 2014-től azonban ismét feltűnt a színen, mert minden más rendszernél kisebb a tömege, illetve olcsóbb is azoknál. Az IMI sokáig elzárkózott a Rafaellel való együttműködéstől, de nemrégiben ez az akadály is elhárult a további fejlesztések elől. 2016-ban az USA Védelmi Minisztérium a számos könnyű és közepes páncélost lefedni kívánó Moduláris Aktív Védelmi Rendszer (MAPS) program központi elemévé tette az Iron Fist-et [21]. Az immár MAPS néven, az amerikai BAE Systems gyámkodásával futó projekt iránt Hollandia is érdeklődik, és vizsgálni kívánja az eszközt.

\section{IRON CURTAIN}

Magyarországon kicsit furcsán cseng a „vasfüggöny” név, de jól érzékelteti a tervezők szándékát. Az amerikai Artis cég 2005 óta fejleszti rendszerét, amely a jól bevált „C" sávú radar és repesztöltetek kombinációja. Kimondottan könnyű páncélosok védelmére, és az aszimmetrikus hadviselés jegyében, elsősorban páncéltörő rakéták ellen szánták [22], így közvetlen piaci ellenfele a Trophy LV-ösnek. Rendszeresítéséről, harci bevetésről nincs információ, a MAPS elindulásával valószínűleg beszüntetik a fejlesztését.

\section{QUICK KILL}

A „gyors ölés” fantázianevű eszközt 2007 környékén az amerikai Raytheon cég alkotta meg a hagyományos radarrepesz recept alapján. Miután a Trophy-val való összeha-

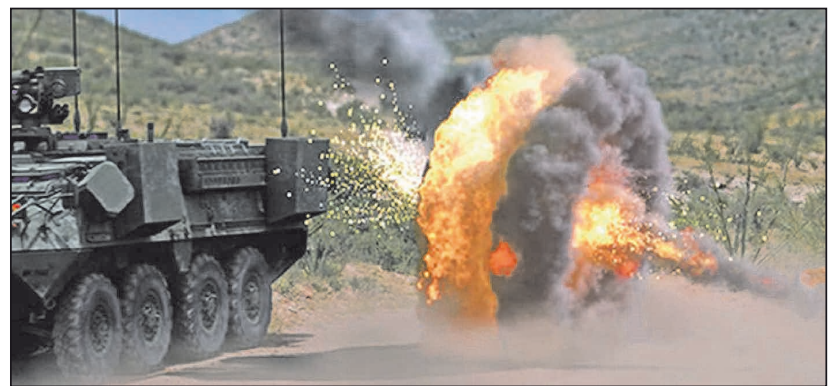

13. ábra. A Quick Kill APS múködés közben

sonlításokban rendre rosszabbul szerepelt, a Raytheon 2013-ban még utoljára demonstrálta a rendszer „egyedülálló" képességeit, de azóta nincs hír róla.

\section{ZASLON}

Miután a szovjet időkben a Drozd fejlesztését és gyártását részben Ukrajnában végezték, a birodalom széthullása után ott is megpróbálták a megszerzett tapasztalatokat hasznosítani. Az azóta megszűnt Mikrotek cég 2003-ban mutatta be a "gát" nevű moduláris készletet, amelyet a jellemzően posztszovjet harckocsik reaktív kazettáinak helyére képzelt felszerelni. A rendszer reakcióideje a fejlesztők szerint minden más rendszernél jobb, így a járműhöz közelebb, kisebb töltettel és környező személyeket kevésbé veszélyeztetve képes a közeledő rakétákat megsemmisíteni. A Mikrotek felszámolása után az állami Ukroboronservice [23] karolta fel a tervet, de mindeddig nem kapott megrendelést.

\section{$A M A P-A D S$}

A németek is kifejlesztették a maguk hard-kill rendszerét. Az AMAP-ADS-t (Active Defense System) számos jármüvön kipróbálták és kiállításokon is bemutatták. A Zaslon filozófiáiához hasonlóan, rendkívül gyors reakcióidejének (560 $\mu \mathrm{sec}$ ) köszönhetően, a környezetre minimális veszélyt jelentve pusztítja el a célt. A rendszer különlegessége, hogy nem csupán a sebesség alapján osztályozza a lehetséges célokat, még a 7,62 mm-es lőszert is képes érzékelni, de nem azonosítja lehetséges fenyegetésként, és nem vált ki rá ellencsapást.

\section{EGYÉB TERVEK}

A svéd SAAB LEDS-150-es néven fejleszti saját eszközét, amely kombinálja a soft- és a hard-kill képességeket. A tervet Dél-Afrika is támogatja, de egyéb információ nem került nyilvánosságra.

A német Diehl cég koordinálta a több hadiipari cég által közösen fejlesztett AWISS-t. A kísérleti fázisba jutott eszközről 2006 óta nincs információ.

Természetesen Kína is bekapcsolódott a versenybe. A mindössze GL5-ösként említett eszközt csak 2017 nyarán tárta a fejlesztő The China North Industries Group Corporation (NORINCO Group) cég a nyilvánosság elé, képességeiről nem tudunk semmit.

\section{A FEJLESZTÉS TOVÁBBI IRÁNYAI}

Ahogy a harckocsik védelmének növelésére korábban használt eljárások technológiai korlátokba ütköztek, teljesen logikus az aktív védelmi rendszerek létrejötte. Manap- 


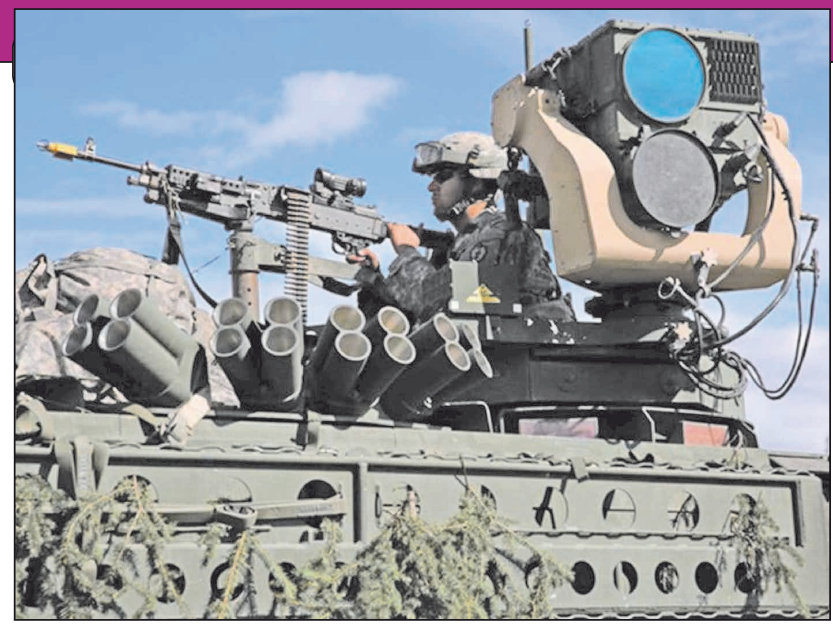

14. ábra. A 196. gyalogos dandár Stryker harcjármúve APS-szel felszerelve

ság egyre több hadsereg és hadiipari cég ismeri fel, hogy a hagyományos módokon már nem lehet számottevő módon növelni a harckocsik harcértékét, míg az APS-ben még óriási a fejlesztési potenciál. Természetesen egyelőre korai erről beszélni, de elvben elképzelhető, hogy az APSek elterjedésével és a hatékonyságuk javulásával megindul egy olyan trend, ami a páncélzat csökkentését és a mozgékonyság javulását hozza magával. Magára a páncéltestre a jelen elvek szerint mindenképpen szükség van, hiszen nem lehet minden kis ürméretű lőszerre aktív ellencsapást indítani, illetve bizonyos páncéltörő eszközök (űrméret alatti lőszerek) esetében jelenleg az APS-ek még csupán azok páncélátütő képességét tudják mérsékelni, de magát a becsapódást nem képesek megakadályozni. Amennyiben azonban az aktív védelmi eszközök képesek lesznek a jelenlegi passzív-reaktív páncélzattal egyenértékű védettséget nyújtani, újra kell majd definiálni azok szerepét.

Azt is tudomásul kell venni ugyanakkor, hogy bár az APS jelenleg egy nagyon hatékony védelmi módnak tűnik, ám semmiképpen sem jelenti, hogy ezzel vége a fejlesztéseknek. A csecsen harcok tapasztalata alapján terjednek az ún. tandem elrendezésű páncéltörő rakéták. Ezeknél a tényleges páncéltörő eszközt megelőzi egy kisebb „csali” töltet. Ez kiváltja az APS-ek ellencsapását, de a repeszek robbanása a másodperc törtrészére megvakítja a radart is. Ha a fő töltet abban a kis időben csapódik be, amíg a radar ismét képes a detekcióra, illetve a rendszer újratölti az ellentölteteket, tulajdonképpen „csak” a passzív páncélzatot kell leküzdenie. A spirál itt sem ér véget, az Afganit állítólag már képes a tandem-lőszereket is felismerni és védekezni ellenük. Ha ez a hír igaz is, magát az eljárást az orosz fejlesztők egyelőre nem tárták a nyilvánosság elé.

Elgondolkodtató, hogy úgy tűnik, mintha az APS-ek fejlesztésében messze a világ előtt járna Oroszország és Izrael, akik egyébként is gyakorta alkalmaznak „unortodox" módszereket harceszközeik hatékonyságának növelése érdekében. Az Egyesült Államok rohamléptekben igyekszik (részben az izraeli technológiára építve) felzárkózni, illetve Kína is bekapcsolódott a versenybe, de érdekes, hogy az egyébként komoly hadiiparral rendelkező európai hatalmak (a német és svéd próbálkozások kivételével) még nem hallattak magukról. Persze azt is látni kell, hogy az elv maga nagyon egyszerü, a gyakorlati megvalósításhoz csúcstechnológia szükséges. Az alkalmazott rendkívül magas frekvencián dolgozó lokátorok, csak néhány 10 méterről érzékelik a csaknem hangsebességgel (de akár jóval gyorsabban) közeledő célokat és mindőssze a másodperc ezredrésze áll rendelkezésükre, hogy azonosítsák azokat, és a fenyegetések ellen aktiválják az ellencsapást.

Jelen állás szerint a hard-kill módszer terjedése a valószínűbb, mert a soft-kill rendszerek bizonyos lövedékek ellen semmilyen védelmet nem nyújtanak. Az orosz Shtora nagy előnye a kis méret és tömeg volt, ezt azonban a folyamatos fejlesztések nyomán lassan behozzák a hard-kill eszközök. Problémát jelent, hogy továbbra sem megoldott a környező saját csapatok védettsége a repeszektől. Amint a légvédelmi lokátorok ellen kifejlesztenek olyan fegyvereket, amit azok kisugárzása alapján vezetik magukat célra, az APS-ek kisugárzása is alkalmas lehet elhárító fegyverek célravezetésére. Az aszimmetrikus hadviselésnél ez nem jelent problémát, de a komoly elektronikai felderítési képességekkel bíró reguláris hadseregek összecsapása esetén az biztos, hogy az APS-ek kisugárzása mellett igen nehéz lesz a harckocsik álcázása. Jelenleg nem megoldott a rendszerek tápellátása sem. Amíg a passzív páncélzat álló helyzetben is védelmet nyújt, a komoly áramfelvételt jelentő lokátorok miatt az APS-ek működéséhez gyakorlatilag folyamatosan járatni kell a harckocsi motorját, vagy valamilyen kiegészítő áramforrást kell alkalmazni az álóhelyzeti működtetéshez, mint az Armata esetében meg is tették [14, 24. o.]. Mindkettő nagyban megnehezíti a harckocsi hatékony álcázását, illetve az üzemanyag-fogyasztás növekedése logisztikai kérdéseket is felvet.

\section{FELHASZNÁLT IRODALOM}

[14] Cifka Miklós: Az új T-14 Armata orosz harckocsi. In: Haditechnika, 2016. 50. évf. 1. sz, p. 19-25.;

[15] Tyler Rogoway: The Seven Deadliest Naval Close-In Weapon Systems. Foxtrot Alpha, 2014.04.27 http:// foxtrotalpha.jalopnik.com/the-seven-deadliest-navalclose-in-weapon-systems-1568291678 [2016.05.30.]

[16] Система активной защиты “Дрозд-2". http://armor. kiev.ua/ptur/azt/drozd2.html [ 2016.05.30.];

[17] ARENA-E Active Protection System for AFV. Defense Update, 2006.07.26, http://defense-update.com/ products/a/arena-e.htm [2017. 09.0 6.];

[18] SHTORA-1 Active Defense System. Defense Update, 2005.10.12. http://defense-update.com/products/s/ shtora-1.htm [2017. 09. 06.];

[19] Afganit. Deagel.com, 2017.04.07. http://www.deagel. com/Protection-Systems/Afganit_a003278001.aspx [2017. 09. 06.];

[20] Trophy family. Rafael. http://www.rafael.co.il/ Module/ImageDownload.aspx $\mathrm{fl}=532 \& \mathrm{cs}=15 \mathrm{BB} 7 \mathrm{~F} 10$ 547E8CDD63F0398E0DE6DCE18391ACED [2017. 09. 07.];

[21] U.S. has chosen Israeli Iron Fist active protection system to secure armoured personnel carrier. ArmyRecognition [2016. 09. 08.]; http:// armyrecognition.com/june_2016_global_defense_ security_news_industry/u.s._has_chosen_israeli_iron fist_active_protection_system_to_secure_armoured_ personnel_carrier_10906162.html [2017.09. 07.];

[22] David Crane: Artis Iron Curtain Active Protection System (APS). Defense Review, 2009.08.30. http:// www.defensereview.com/artis-iron-curtain-activeprotection-system-aps-shoot-down-ballistic-reactiveground-vehicle-defense-system/ [2017. 09. 07.];

[23] The active protection system ZASLON. Ukroboronservice. https://en.uos.ua/produktsiya/ sistemi-zashchiti/49-kompleks-aktivnoy-zashchitizaslon [2017. 09. 07.];

[24] Gyarmati József - Kende György - Turcsányi Károly: Tüzérségi tűzvezető rendszerek összehasonlítása Katonai Logisztika 2002. évi 2. sz. pp. 137-161. 